\title{
EFFECT OF IRRIGATION ON THE PRODUCTIVITY AND WATER USE EFFICIENCY OF FABA BEAN CULTIVARS (Vicia faba L) IN NORTH DELTA, EGYPT El-Bably, A. Z. ${ }^{1}$ and R.A.I. Abo-Mostafa ${ }^{2}$ 1-Soils, Water and Environment Research Institute, A.R.C., Giza, Egypt 2- Field crops Research Institute, ARC., Giza, Egypt
}

\begin{abstract}
Two field experiments were conducted at Sakha Agricultural Research station, Kafr El-Sheikh governorate, during the two successive seasons of 2005/06 and 2006/07. The study aimed to investigate irrigation effect on seed yield and water use efficiency of faba bean cultivars in North Delta, Egypt. A split plot design with four replications was used. Irrigation treatments were sowing irrigation $\left(\mathrm{I}_{1}\right)$; sowing irrigation plus $1^{\text {st }}$ irrigation after 30 days from sowing $\left(I_{2}\right)$; sowing irrigation plus $1^{\text {st }}$ irrigation after 30 days and the $2^{\text {nd }}$ irrigation after 90 days from sowing ( $\left.I_{3}\right)$; sowing irrigation plus $1^{\text {st }}$ irrigation after 30 days and the $2^{\text {nd }}$ irrigation after 90 days and the $3^{\text {rd }}$ irrigation after 120 days from sowing (14). Sub plots were devoted to faba bean cvs. Sakha 1, Sakha 3 and Nubaria 1.

Results showed that insignificant increases between irrigation treatment of $\mathbf{I}_{4}$ and treatment of $I_{3}$ in all traits under study i.e. plant height, number of pods/plant, number of seeds/pods, number of seeds/plant, 100-seed weight, seed yield of plant and seed yield. Irrigation treatment of $\mathrm{I}_{4}$ significantly increased plant height by $4.7 \%$, number of seeds/plant by $22.1 \%, 100$-seed weight by $4.1 \%$, and seed yield/fed by $22.4 \%$ compared to irrigation treatment of $I_{1}$.

Means values of seasonal water consumptive use of faba bean were 30.05 $\mathrm{cm}, 25.84 \mathrm{~cm}, 22.49 \mathrm{~cm}$, and $12.30 \mathrm{~cm}$ for irrigation treatments of $\mathrm{I}_{4}, \mathrm{I}_{3}, \mathrm{I}_{2}, \mathrm{I}_{1}$, respectively. Faba bean cv. Sakha 1 consumed less water than cvs. Sakha 3 and Nubaria 1 by $7.4 \%$ and $4.9 \%$, respectively, due to short duration of cv. Sakha 1 .

Seasonal irrigation water applied were $47.2 \mathrm{~cm}\left(1982 \mathrm{~m}^{3} / \mathrm{fed}\right.$.), $39.1 \mathrm{~cm}(1642$ $\mathrm{m}^{3} / \mathrm{fed}$.), $27.6 \mathrm{~cm}\left(1159 \mathrm{~m}^{3} / \mathrm{fed}\right.$.), and $18.8 \mathrm{~cm}\left(790 \mathrm{~m}^{3} / \mathrm{fed}\right.$.) for irrigation treatments of $I_{4}, I_{3}, I_{2}, I_{1}$, respectively.

Maximum values of crop water use and field water use efficiencies resulted from irrigation treatment of $I_{1}$, and faba bean $c v$. Sakha 3 exhibited the highest crop water use and field water use efficiencies compared to the other tested cultivars.

Means percentage values of water removed from the upper $30 \mathrm{~cm}$ soil layer were $76.93 \%, 72.20 \%, 66.43 \%$ and $63.48 \%$ for $\mathrm{I}_{4}, \mathrm{I}_{3}, \mathrm{I}_{2}$, and $\mathrm{I}_{1}$ respectively.

Regression slope indicated that each centimeter of seasonal water applied produced $10.5 \mathrm{~kg}$ seed yield/fed. and enhanced water consumptive use of faba bean plants by $0.60 \mathrm{~cm}$. On the other hand, it decreased crop water use efficiency by $1.7 \mathrm{~kg}$ seed yield/cm of water consumed and field water use efficiency by $1.3 \mathrm{~kg}$ seed yield/cm of water applied.

Therefore, irrigating faba bean plants 3 times including sowing irrigation could be applied since the reduction in seeds yield was $1.4 \%$ for $17.2 \%$ of saving irrigation water applied compared with irrigation 4 times including sowing irrigation. But, when water is scarce, irrigations may be reduced to two, or one, which concomitant water savings, using cultivars which utilize more water and result in higher water use efficiencies in Delta, Egypt.
\end{abstract}




\section{INTROUCTION}

Faba bean (Vicia faba L.) is one of the major winter sown legume crops grown in the Mediterranean region, and has considerable importance as a low cost food rich in proteins and carbohydrates in Egypt. The total production in 2004/05 was about 282.000 tons, while the total consumption was estimated to be about 420.000 tons. This means that the percentage of self-sufficiency is only about $67 \%$ (Amer et al. 2006). So, to reduce the gab between production and consumption, the most effective is being developing new cultivars with high yielding potentiality in addition using the proper management.

Farmers in North Delta, Egypt, generally irrigate winter faba bean two to four times, including sowing irrigation, depending on average rainfalls during the growing season from October to May ranged from approximately 67-200 mm (Egyptian Meteorological Authority, 1960).

Substantial and sustainable improvements in the productivity of faba bean can be achieved through integrated farm-resources management, such as on-farm water-productive techniques, high yielding faba bean cultivars selection and appropriate cultural practices which will help to achieve this objective.

El-Galfy, (2005), revealed that the yield and its components of faba bean (plant height, number of branches per plant, number of pods per plant, number of seeds per pod, pod weight, 100-seed weight and seed yield/fed) significantly decreased as the number of irrigations decreased. The yield decreased by $52 \%$ and $15.5 \%$ with one and two irrigations, respectively, compared to three irrigations. This reduction in yield may be due to lower number of branches, pods, seeds per plant, pod weight and 100-seed weight. Irrigation frequency 4 times after planting appeared to be optimum for obtaining high seed yield of faba bean (Mohamed et al., 1999). Hassanein (2000) showed that Giza 643 subjected to 2 irrigations at 60 and 90 days after sowing or 3 irrigations at 60,90 and 120 days after sowing recorded the highest seed yield, whereas Giza Blanka subjected to 3 irrigations recorded the highest straw yield. Xia (1997) showed that plants subjected to drought from initiation of pod-set to full pod-set produced $32 \%$ less total dry matter and $45 \%$ less seed yield than the irrigated control. Only plants subjected to drought from full pod-set to maturity had a significant lower mean seed weight than the control (well irrigated). Meleha et al.(2004) indicated that the highest seed yield of faba bean of $1792.6 \mathrm{~kg} / \mathrm{fed}$ resulted from the treatment received $51.2 \mathrm{~cm}$, while the lowest seed yield was $1731.4 \mathrm{~kg} / \mathrm{fed}$ resulted from the treatment received $53.1 \mathrm{~cm}$. They also revealed that actual water consumptive use amounted to $36.7-38.1 \mathrm{~cm}$ when the amount of water applied ranged from 49.3 to $53.1 \mathrm{~cm}$, and water use efficiency increased with decreasing irrigation water applied. Fardos and Abdel-Nour (2000), found that maximum faba been seed yield was gained from treatment irrigated frequently at $30 \%$ available soil moisture depletion (ASMD). Seasonal water consumptive use of faba bean ranged from $344 \mathrm{~mm}$ for irrigating at $90 \%$ ASMD to $521.3 \mathrm{~mm}$ for irrigating at 30\% ASMD. The maximum WUE was 
obtained from irrigation at 60\% ASMD. Plies et al. (1995) and Tawardros et al. (1993) found that the drought conditions during flowering stage significantly decreased yield formation in all cultivars under study, whereas water stress during pod filling stage had little effect on biomass production. This was in agreement with that of Farah et al. (1990), who found that water shortage greatly affected faba bean yield. Abd El-Mottaleb and Abbas (1992), found that the highest water consumptive use $\left(1497 \mathrm{~m}^{3} / \mathrm{fed}\right.$.) was obtained when soil moisture suction is kept at 2 bars, while the lowest value were 840 $\mathrm{m}^{3} / \mathrm{fed}$. at 10 bars. Abbas et al., (1994) revealed that maximum yield of seed and straw were recorded by irrigation of the faba bean plants at 6 bars. Water consumptive use by faba bean ranged from 35.9 to $37.1 \mathrm{~cm}$. Ainer et al. (1993) indicated that the optimum yield of faba bean seeds was obtained by irrigating the crop at 2 bars in the Delta region, and the water use efficiency decreased when the faba bean was irrigated at 10 bars. They also added that water consumptive use of faba bean ranged from 170.2 to $370.5 \mathrm{~mm}$ at Sakha region (North Delta).

As for faba bean cultivars, El-Deep et al. (2006) revealed that planting $1706 \mathrm{~B} / 87 / 1999$ genotype resulted in higher faba bean yields by $7.2 \%, 15.6 \%$ and $7.2 \%$ compared to genotype 1706B/39/1999, cvs. Misr 2 and Giza 40.

The objective of this investigation was to study the effect of irrigation on seed yield productivity of faba bean cultivars and water use efficiency in North Delta, Egypt.

\section{MATERIALS AND METHODS}

The investigation was conducted at Sakha Agricultural Research Station, Kafr El-Sheikh Governorate, during seasons of 2005/06 and 2006/07.

A split-plot design with four replications was used. Main plots were occupied to irrigation treatments which were sowing irrigation $\left(I_{1}\right)$; sowing irrigation plus $1^{\text {st }}$ irrigation after 30 days from sowing $\left(I_{2}\right)$; sowing irrigation plus $1^{\text {st }}$ irrigation after 30 days and the $2^{\text {nd }}$ irrigation after 90 days from sowing $\left(\mathrm{l}_{3}\right)$; sowing irrigation plus $1^{\text {st }}$ irrigation after 30 days and the $2^{\text {nd }}$ irrigation after 90 days and the $3^{\text {rd }}$ irrigation after 120 days from sowing (14). Sub plots were devoted to faba bean cvs. Sakha 1, Sakha 3 and Nubaria 1.

The soil was clayey in texture, whereas particle size distribution was $52.10 \%$ clay, $27.23 \%$ silt and $20.67 \%$ sand. Soil pH (1: 2.5) was 8.12 and the electrical conductivity of soil and irrigation water was 2.35 and $0.45 \mathrm{dSm}^{-1}$, respectively, the analysis was determined according to Page (1982). The plots were isolated by ditches of $1.5 \mathrm{~m}$ in width to avoid lateral movement of irrigation water to adjacent plots. The area of each sub plot is $42 \mathrm{~m}^{2}(6 \times 7$ $\mathrm{m}^{2}$ ).

Sowing dates in the first and second seasons were on November $7^{\text {th }}$ and $10^{\text {th }}$, respectively. All cultural practices for faba bean were applied. Faba bean plants were harvested on $5^{\text {th }}$ and $7^{\text {th }}$ May in the first and second growing seasons for cvs. Sakha 3 and Nubaria 1, respectively, and on $12^{\text {th }}$ and $14^{\text {th }}$ April for $\mathrm{cv}$. Sakha 1 
Ten guarded plants were randomly taken from each plot to measure plant height in $\mathrm{cm}$, number of pods/plant, number of seeds/pod, number of seeds/plant, 100-seed weight in g, and seed yield/fed in ardab (ardab $=155$ $\mathrm{kg}$ ). Seed yield/fed. was obtained from central area of each plot (1/300 fed.) to avoid any border effect.

Data were subjected to the combined analysis as described by Snedecor and Cochran (1980). The treatment means were compared according to Duncan's multiple range test (Duncan, 1955). Also, a regression and simple correlation coefficient between seasonal irrigation water applied and each of seed yield, water consumptive use and crop water use efficiency was computed according to the method described by Snedecor and Cochran (1980).

Data of Sakha meteorological station recorded air temperature, relative humidity, and rainfall distribution, during 2005/06 and 2006/07 seasons, are presented in Table 1.

\section{Soil water relations:}

Soil moisture content was gravimetrically determined in soil sample taken from consecutive depth of $15 \mathrm{~cm}$ down to a depth of $60 \mathrm{~cm}$. For irrigation timing, soil samples were also collected just before each irrigation, 48 hours after irrigation and at harvest time, to estimated water consumptive use (Hansen et al., 1979). Field capacity, permanent wilting point and bulk density were determined according to Klute (1986), and are given in Table 2.

Table (1):Sakha meteorological data of Agricultural Research Station during 2005/06 and 2006/07 seasons.

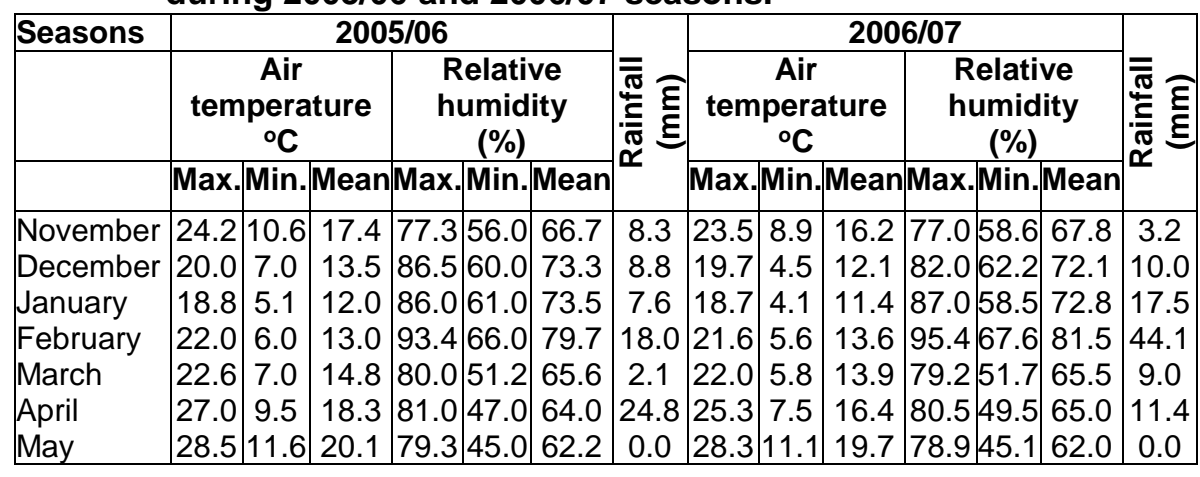

Table (2): Soil moisture constants for the experimental site.

\begin{tabular}{|c|c|c|c|c|}
\hline $\begin{array}{c}\text { Soil depth } \\
\text { (cm) }\end{array}$ & $\begin{array}{c}\text { Field capacity } \\
(\%)\end{array}$ & $\begin{array}{c}\text { Wilting point } \\
(\mathbf{\%})\end{array}$ & $\begin{array}{c}\text { Bulk density } \\
\left(\mathbf{g} / \mathbf{c m}^{\mathbf{3}}\right)\end{array}$ & $\begin{array}{c}\text { Available } \\
\text { soil water (\%) }\end{array}$ \\
\hline $0-15$ & 46.14 & 24.78 & 1.11 & 21.36 \\
$15-30$ & 41.21 & 21.29 & 1.21 & 19.92 \\
$30-45$ & 36.84 & 20.38 & 1.24 & 16.46 \\
$45-60$ & 34.91 & 19.13 & 1.32 & 15.78 \\
\hline Mean & 39.78 & 21.40 & 1.22 & 18.38 \\
\hline
\end{tabular}


Irrigation water applied (IWA):

The amount of water applied at each irrigation was determined on the basis of raising the soil moisture content to its field capacity plus $10 \%$ as a leaching requirements. Irrigation water applied was calculated according to the following equation (Michael, 1978).

Where:

$$
d=D^{*} B_{d}{ }^{*} \frac{F_{c}-M_{c}}{100}
$$

$\mathrm{d}=$ amount of water to be applied during an irrigation event, $\mathrm{cm}$.

$\mathrm{D}=$ soil depth within the root zone, $60 \mathrm{~cm}$.

$\mathrm{B}_{\mathrm{d}}=$ soil bulk density, $\mathrm{g} \mathrm{cm}^{-3}$

$\mathrm{F}_{\mathrm{c}} \quad=$ field capacity moisture content (\% by weight).

$M_{c}=$ moisture content before irrigation (\% by weight).

Submerged flow orifice with fixed dimension was used to measure the amount of water applied according to the following equation (Michael, 1978).

Where:

$$
Q=C A \sqrt{2 g h}
$$

$\mathrm{Q}=$ discharge through orifice, (1/sec.)

$\mathrm{C}=$ coefficient of discharge, (0.61).

A $=$ cross-sectional area of the orifice, $\left(\mathrm{cm}^{2}\right)$

$\mathrm{g}=$ acceleration of gravity, $\left(\mathrm{cm} / \mathrm{sec}^{2}\right)(981 \mathrm{~cm} / \mathrm{sec}$. $)$.

$\mathrm{h}=$ pressure head, causing discharge through the orifice $(\mathrm{cm})$.

Crop water use efficiency (CWUE):

Crop water use efficiency was calculated according to Michael (1978).

Where:

$$
\text { CWUE }=\text { Y/C.U }
$$

$\mathrm{Y} \quad=$ seed yield in $\mathrm{kg}$

$\mathrm{C} . \mathrm{U}=$ seasonal water consumptive use in $\mathrm{cm}$.

Field water use efficiency (FWUE):

It was calculated according to Jensen (1983).

$$
\text { FWUE }=\frac{\text { Seed yield in } \mathrm{kg}}{\text { Amount of applied water }(\mathrm{cm})}
$$

\section{Soil moisture extraction pattern (SMEP):}

It was calculated according to the following equation (Hansen et al., 1979).

\section{Where:}

$$
\text { SMEP }=\text { CU. (layer) } \times 100 / C U \text { (seasonal) }
$$

$\mathrm{CU}$. (layer) = sum of extracted soil moisture in each soil layer $(15 \mathrm{~cm})$.

$\mathrm{CU}($ seasonal $)=$ total sum of moisture extracted in all soil layers $(60 \mathrm{~cm})$. 


\section{RESULTS AND DISCUSSION}

\section{Seed yield and its attributes:}

Mean values of all studied characters as affected by irrigation and faba bean cultivars in the combined analysis over the two growing seasons are presented in Table (3). Results in Table (3) showed that higher values of seed yield and its components resulted from irrigation treatments of $I_{3}$ and $I_{4}$, respectively, without any significant difference between them. Irrigation treatment of $\mathrm{I}_{4}$ significantly increased plant height by $4.7 \%$, number of seeds/plant by $22.1 \%, 100$-seed weight by $4.1 \%$, and seed yield/fed by $22.4 \%$ compared to irrigation treatment of $\mathrm{I}_{1}$. Seed yield for faba bean of both $I_{4}$ and $I_{3}$ irrigation treatments was higher than irrigation treatment of $I_{1}$ because of higher yield components such as number of pods/plant, number of seed/pod, number of seeds/plant and 100-seed weight as shown in Table (3). Data in Table 3 revealed that number of pods/plant and number of seeds/pod were not significantly affected by irrigation treatments.

A higher yield and its attributes of faba bean plants was gradually increased as a result of increasing in the availability of soil moisture content in root zone which increase seed yield. Similar results were obtained by Fardos and Abdel-Nour (2000), Hassanein (2000), and El-Galfy (2005), who revealed that the yield and its components of faba bean significantly was decreased as the number of irrigations decreased. In the absence of water stress, a longer post-flowering duration allowed the indeterminate to develop a larger canopy and achieve a high final biomass (Sau and Minguez, 2000, Shawky, et al. 2004 and Costa et al. 1997). Water stress generally decreased the number of stomata on both leaf surfaces and decreased stomatal opening. Therefore, water stress decreased the rate of $\mathrm{CO}_{2}$ fixation and inhibited the metabolism of soluble to insoluble photosynthates (Younis, et al. 1993).

Data in Table 3 revealed that faba bean cv. Sakha 1 significantly surpassed cvs. Sakha 3 and Nubaria 1 in plant height and number of seeds/plant On the other hand, faba bean cv. Nubaria 1 surpassed faba bean cvs. Sakha 1 and Sakha 3 in 100-seed weight. Faba bean cv. Sakha 3 significantly surpassed cvs. Sakha 1 and Nubaria 1 in seed yield/fed. These differences may be due to the genetic differences among faba bean cultivars. The results are in agreement with those obtained by Amede et al. (1999) and Amer et al. (2006) and El-Deep et al. (2006). Results in Table 3 revealed that number of pods/plant and number of seeds/pod were not significantly affected by faba bean cultivars.

Insignificant effect of irrigation and season interaction was obtained from all traits. Such results indicated that irrigation treatments showed similar effect from season to season. The interaction between irrigation $x$ faba bean cultivars was not significant except the interaction between irrigation and cultivars on plant height, number of seeds/plant, 100-seed weight, and seed yield/fed. as shown in Table (3). All traits under study was not significantly affected by the interaction of irrigation $x$ faba bean cultivars $x$ season (Table 3 ). 
Table (3): Mean values of faba bean yield and its attributes as affected by irrigation treatments and cultivars in the combined analysis over both seasons

\begin{tabular}{|c|c|c|c|c|c|c|}
\hline Treatments & $\begin{array}{l}\text { Plant } \\
\text { height } \\
(\mathrm{cm})\end{array}$ & $\begin{array}{l}\text { No. of } \\
\text { pods/ } \\
\text { plant }\end{array}$ & $\begin{array}{l}\text { No. of } \\
\text { seeds/ } \\
\text { pod }\end{array}$ & $\begin{array}{l}\text { No. of } \\
\text { seeds/ } \\
\text { plant }\end{array}$ & $\begin{array}{l}\text { 100-seed } \\
\text { weight } \\
\text { (g) }\end{array}$ & $\begin{array}{c}\text { Seed } \\
\text { yield. } \\
\text { (ardab/fed) }\end{array}$ \\
\hline 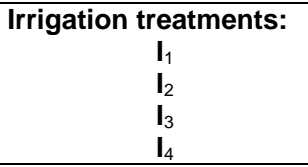 & $\begin{array}{l}116.0 \mathrm{~b} \\
117.9 \mathrm{~b} \\
120.2 \mathrm{a} \\
121.4 \mathrm{a} \\
\end{array}$ & $\begin{array}{l}6.1 \\
6.5 \\
7.0 \\
7.1 \\
\end{array}$ & $\begin{array}{l}2.8 \\
2.9 \\
3.0 \\
3.0 \\
\end{array}$ & $\begin{array}{l}17.2 \mathrm{c} \\
19.0 \mathrm{~b} \\
21.0 \mathrm{a} \\
21.0 \mathrm{a} \\
\end{array}$ & $\begin{array}{l}88.4 \mathrm{c} \\
90.1 \mathrm{~b} \\
91.7 \mathrm{a} \\
92.0 \mathrm{a}\end{array}$ & $\begin{array}{r}8.65 \mathrm{c} \\
9.76 \mathrm{~b} \\
10.44 \mathrm{a} \\
10.59 \mathrm{a} \\
\end{array}$ \\
\hline $\begin{array}{c}\text { Faba bean cultivars: } \\
\text { Sakha } 1 \\
\text { Sakha } 3 \\
\text { Nubaria } 1\end{array}$ & $\begin{array}{l}132.0 \mathrm{a} \\
106.7 \mathrm{c} \\
118.0 \mathrm{~b}\end{array}$ & $\begin{array}{l}7.6 \\
7.0 \\
5.5\end{array}$ & $\begin{array}{l}2.9 \\
2.8 \\
3.0\end{array}$ & $\begin{array}{l}22.2 \mathrm{a} \\
20.0 \mathrm{~b} \\
16.7 \mathrm{c}\end{array}$ & $\begin{array}{c}76.5 c \\
90.8 b \\
104.4 a\end{array}$ & $\begin{array}{c}9.21 \mathrm{c} \\
10.45 a \\
9.91 b\end{array}$ \\
\hline $\begin{array}{l}\text { Interactions: } \\
\text { Irrig. } x \text { season } \\
\text { Irrig. x cultivars. } \\
\text { Irrig. } \text { x cultivars } \text { x season }\end{array}$ & $\begin{array}{l}\text { N.S } \\
* * \\
\text { N.S }\end{array}$ & $\begin{array}{l}\text { N.S } \\
\text { N.S } \\
\text { N.S }\end{array}$ & $\begin{array}{l}\text { N.S } \\
\text { N.S } \\
\text { N.S }\end{array}$ & $\begin{array}{l}\text { N.S } \\
* \star \\
\text { N.S }\end{array}$ & $\begin{array}{l}\text { N.S } \\
* * \\
\text { N.S }\end{array}$ & $\begin{array}{l}\text { N.S } \\
* \star \\
\text { N.S }\end{array}$ \\
\hline
\end{tabular}

Means designed by the same letter at each cell are not significantly at the $5 \%$ level according to Duncan's multiple range test.

N.S: Indicate not significant

Data in Table 4 showed that the average values of plant height, number of seeds/plant, 100-seed weight, and seed yield/fed. were significantly affected by the interaction between irrigations treatments and faba bean cultivars, over both seasons.

Table (4): Interaction between irrigation treatments and faba bean cultivars on plant height, number of seed/plant, 100-seed weight and seed yield/fed., over both growing seasons.

\begin{tabular}{|c|c|c|c|c|}
\hline \multirow{2}{*}{$\begin{array}{l}\text { Faba bean } \\
\text { cultivars }\end{array}$} & \multicolumn{4}{|c|}{ Irrigation treatments } \\
\hline & $I_{1}$ & $I_{2}$ & $I_{3}$ & $I_{4}$ \\
\hline & \multicolumn{4}{|c|}{ Plant height $(\mathrm{cm})$} \\
\hline \begin{tabular}{|c|} 
Faba bean cultivars: \\
Sakha 1 \\
Sakha 3 \\
Nubaria 1 \\
\end{tabular} & $\begin{array}{l}128 b \\
103 d \\
117 f\end{array}$ & $\begin{array}{l}130 b \\
106 \mathrm{~cd} \\
118 \mathrm{ef}\end{array}$ & $\begin{array}{l}134 a \\
108 c \\
119 e \\
\end{array}$ & $\begin{array}{l}135 a \\
109 c \\
119 e\end{array}$ \\
\hline & \multicolumn{4}{|c|}{ number of seeds/plant } \\
\hline \begin{tabular}{|c|} 
Faba bean cultivars: \\
Sakha 1 \\
Sakha 3 \\
Nubaria 1 \\
\end{tabular} & $\begin{array}{l}19.8 \mathrm{~b} \\
17.0 \mathrm{c} \\
14.8 \mathrm{~d} \\
\end{array}$ & $\begin{array}{l}21.7 \mathrm{ab} \\
19.0 \mathrm{~b} \\
16.2 \mathrm{~cd}\end{array}$ & $\begin{array}{c}23.7 a \\
21.8 a b \\
17.7 c\end{array}$ & $\begin{array}{c}23.7 \mathrm{a} \\
22.3 \mathrm{ab} \\
18.0 \mathrm{bc}\end{array}$ \\
\hline & \multicolumn{4}{|c|}{ 100-seed weight (g) } \\
\hline $\begin{array}{c}\text { Faba bean cultivars: } \\
\text { Sakha } 1 \\
\text { Sakha } 3 \\
\text { Nubaria } 1 \\
\end{array}$ & $\begin{array}{c}72.8 d \\
89.2 b \\
103.3 a\end{array}$ & $\begin{array}{c}75.7 \mathrm{~cd} \\
90.7 \mathrm{~b} \\
104.0 \mathrm{a}\end{array}$ & $\begin{array}{c}78.7 \mathrm{c} \\
91.4 \mathrm{~b} \\
105.1 \mathrm{a}\end{array}$ & $\begin{array}{c}78.9 \mathrm{c} \\
91.8 \mathrm{~b} \\
105.3 \mathrm{a}\end{array}$ \\
\hline & \multicolumn{4}{|c|}{ Seed yield (ardab/fed.) } \\
\hline \begin{tabular}{|c|} 
Faba bean cultivars: \\
Sakha 1 \\
Sakha 3 \\
Nubaria 1
\end{tabular} & $\begin{array}{l}8.60 \mathrm{e} \\
8.74 \mathrm{e} \\
8.60 \mathrm{e}\end{array}$ & $\begin{array}{l}9.25 \mathrm{~cd} \\
10.16 \mathrm{c} \\
9.88 \mathrm{~d}\end{array}$ & $\begin{array}{l}9.47 \mathrm{~d} \\
11.37 \mathrm{a} \\
10.47 \mathrm{~b}\end{array}$ & $\begin{array}{l}9.53 \mathrm{c} \\
11.53 \mathrm{a} \\
10.70 \mathrm{~b}\end{array}$ \\
\hline
\end{tabular}

Means designed by the same letter at each cell are not significantly different at the $5 \%$ level according to Duncan's multiple range test. 
It is obvious form Table 4 that the highest mean values of plant height was obtained from irrigation treatment of $I_{3}$ and $I_{4}$ with faba bean cv. Sakha 1. However, the lowest value of plant height was obtained from irrigation treatment of $\mathbf{I}_{1}$ with faba bean cv. Sakha 3. Results in Table 4 revealed that faba bean CV. Sakha 1 resulted in higher number of seeds/plant with irrigation treatments of $I_{4}$ and $I_{3}$. While 100-seed weight of faba bean cV. Nubaria 1 was higher than faba bean cvs. Sakha 1 and Sakha 3 under all irrigation treatments. The highest seed yield/fed. was obtained from faba bean cvs. Sakha 3 with irrigation treatments of $I_{4}$ and $I_{3}$. These results could be attributed to the varietal differences (Amer et al. 2006 and El-Deep et al. 2006).

II. Soil water relations:

I. Consumptive use (CU):

Seasonal consumptive use values for faba bean cultivars, as affected by irrigation treatments and faba bean cultivars are presented in Table 5. It is obvious that the consumptive use increased as the irrigation applications increased. Faba bean plants of irrigation treatment of $I_{4}$ has the highest value of water consumption, followed by faba bean plants in the treatments of $I_{3}, I_{2}$ and $I_{1}$, respectively. Means values of seasonal water consumptive use were $30.05 \mathrm{~cm}, 25.84 \mathrm{~cm}, 22.49 \mathrm{~cm}$ and $12.30 \mathrm{~cm}$ for irrigation treatments of $\mathrm{I}_{4}, \mathrm{I}_{3}$, $I_{2}$ and $I_{1}$, respectively. The most probably explanation for these results is that more available soil moisture resulted from more irrigation times give chance for luxury consumption of water, which ultimately resulted in enhancing transpiration from faba bean plants, in addition to high water evaporation from the soil.

Table (5): Monthly and seasonal water consumptive use (cm) as affected by irrigation treatments and faba bean cultivars, over both seasons.

\begin{tabular}{|c|c|c|c|c|c|c|c|c|}
\hline Irrigation & Faba bean & & & & & & & Water \\
\hline treatments & cultivars & Nov. & Dec. & Jan. & Feb. & March & April & $\begin{array}{c}\text { consumptive } \\
\text { use }(\mathbf{c m})\end{array}$ \\
\hline & Sakha 1 & 2.51 & 2.43 & 3.60 & 8.72 & 7.75 & 3.11 & 28.12 \\
\hline $\mathbf{I}_{4}$ & Sakha 3 & 2.51 & 2.43 & 3.41 & 7.66 & 9.94 & 5.52 & 31.47 \\
\hline & Nubaria 1 & 2.51 & 2.43 & 3.40 & 7.61 & 9.12 & 5.50 & 30.57 \\
\hline & $\operatorname{an}$ & 2.51 & 2.43 & 3.47 & 8.00 & 8.94 & 4.71 & 30.05 \\
\hline & Sakha 1 & 2.51 & 2.43 & 3.31 & 6.21 & 7.84 & 3.05 & 25.35 \\
\hline $\mathbf{I}_{3}$ & Sakha 3 & 2.51 & 2.43 & 3.21 & 4.99 & 7.97 & 5.09 & 26.20 \\
\hline & Nubaria 1 & 2.51 & 2.43 & 3.20 & 4.97 & 7.91 & 4.95 & 25.97 \\
\hline & an & 2.51 & 2.43 & 3.24 & 5.39 & 7.91 & 4.36 & 25.84 \\
\hline & Sakha 1 & 2.51 & 2.43 & 3.15 & 5.45 & 5.11 & 3.01 & 21.66 \\
\hline $\mathbf{I}_{2}$ & Sakha 3 & 2.51 & 2.43 & 3.22 & 3.73 & 6.84 & 4.39 & 23.12 \\
\hline & Nubaria 1 & 2.51 & 2.43 & 3.20 & 3.60 & 6.54 & 4.40 & 22.68 \\
\hline & an & 2.51 & 2.43 & 3.19 & 4.26 & 6.16 & 3.93 & 22.49 \\
\hline & Sakha 1 & 2.51 & 2.43 & 1.32 & 1.66 & 2.60 & 1.21 & 11.71 \\
\hline $\mathbf{I}_{1}$ & Sakha 3 & 2.51 & 2.43 & 1.77 & 2.03 & 3.06 & 1.22 & 13.02 \\
\hline & Nubaria 1 & 2.51 & 2.43 & 1.72 & 1.69 & 2.66 & 1.14 & 12.15 \\
\hline & & 2.51 & 2.43 & 1.60 & 1.79 & 2.77 & 1.19 & 12.30 \\
\hline & Sakha 1 & 2.51 & 2.43 & 2.85 & 5.51 & 5.82 & 2.60 & 21.72 \\
\hline Overall & Sakha 3 & 2.51 & 2.43 & 2.90 & 4.60 & 6.95 & 4.06 & 23.45 \\
\hline mean & Nubaria 1 & 2.51 & 2.43 & 2.88 & 4.47 & 6.56 & 4.00 & 22.85 \\
\hline
\end{tabular}


Monthly consumptive use started with low amount of water when faba bean plants were small, then it increased gradually as faba bean plants grow up and reached its peak in March, then it decreased at the end of the season with mature plants. The peak-use period usually occurs when the vegetation is abundant and temperature is high. These results are in agreement with those obtained by Abd El-Mottaleb and Abbas (1992), Abbas et al., (1994), Ainer et al., (1993) and Meleha et al., (2004).

As for faba bean cultivars, data indicated that overall mean values of water comsimptive use by faba bean cvs. Sakha 3 and Nubaria 1 was more than faba bean cv. Sakha 1 by $8.0 \%$ and $5.2 \%$, respectively, as shown in Table 5.

\subsection{Irrigation water requirements (IWR):}

Results in Table 6 indicated that irrigation treatment of $\mathrm{I}_{4}$ required the highest amount of water applied to be $47.2 \mathrm{~cm}\left(1982 \mathrm{~m}^{3} / \mathrm{fed}\right.$.), followed by the treatments of $I_{3}, I_{2}$, and $I_{1}$ to be $39.1 \mathrm{~cm}\left(1642 \mathrm{~m}^{3} / \mathrm{fed}\right.$.), $27.6 \mathrm{~cm}(1159$ $\mathrm{m}^{3} / \mathrm{fed}$.), and $18.8 \mathrm{~cm}\left(790 \mathrm{~m}^{3} / \mathrm{fed}\right.$.), respectively. Sowing irrigation was the same for all irrigation treatments. The average of the effective rainfall was 5.8 $\mathrm{cm}$ over both growing seasons. It is obvious that amount of irrigation water applied was gradually increased as a result of growing up of a vegetative growth that required higher amount of irrigation to meet its water requirements, and then it decreased again. Theses findings may be attributed to growth stages, and the availability of soil water content in the root zone.

Table (6): Amounts of seasonal irrigation water applied (cm) as affected by the different irrigation treatments, as well as the amounts of effective rainfall $(\mathrm{cm})$, over both seasons.

\begin{tabular}{|c|c|c|c|c|c|}
\hline Variables & Date & \multicolumn{4}{|c|}{ Irrigation treatments } \\
\hline & & $I_{4}$ & $\mathrm{I}_{3}$ & $I_{2}$ & $I_{1}$ \\
\hline Sowing irrigation & Nov. $8^{\text {th }}$ & $\begin{array}{c}12.95 \mathrm{~cm} \\
\left(544 \mathrm{~m}^{3} / \text { fed. }\right)\end{array}$ & $\begin{array}{c}12.95 \mathrm{~cm} \\
\left(544 \mathrm{~m}^{3} / \mathrm{fed} .\right)\end{array}$ & $\begin{array}{c}12.95 \mathrm{~cm} \\
\left(544 \mathrm{~m}^{3} / \mathrm{fed} .\right)\end{array}$ & $\begin{array}{c}12.95 \mathrm{~cm} \\
\left(544 \mathrm{~m}^{3} / \text { fed. }\right)\end{array}$ \\
\hline The first irrigation & Dec., $8^{\text {th }}$ & $\begin{array}{c}8.85 \mathrm{~cm} \\
\left(372 \mathrm{~m}^{3} / \mathrm{fed} .\right)\end{array}$ & $\begin{array}{c}8.85 \mathrm{~cm} \\
\left(372 \mathrm{~m}^{3} / \mathrm{fed} .\right)\end{array}$ & $\begin{array}{c}8.85 \mathrm{~cm} \\
\left(372 \mathrm{~m}^{3} / \mathrm{fed} .\right)\end{array}$ & \\
\hline The second irrigation & Feb., $7^{\text {th }}$ & $\begin{array}{c}11.50 \mathrm{~cm} \\
\left(483 \mathrm{~m}^{3} / \text { fed. }\right)\end{array}$ & $\begin{array}{c}11.50 \mathrm{~cm} \\
\left(483 \mathrm{~m}^{3} / \mathrm{fed} .\right)\end{array}$ & & \\
\hline The third irrigation & $\begin{array}{l}\text { March, } \\
9^{\text {th }}\end{array}$ & $\begin{array}{c}8.10 \mathrm{~cm} \\
\left(340.2 \mathrm{~m}^{3} / \text { fed. }\right)\end{array}$ & & & \\
\hline Irrigation water applied & & $\begin{array}{c}41.4 \mathrm{~cm} \\
\left(1739 \mathrm{~m}^{3} / \mathrm{fed} .\right)\end{array}$ & $\begin{array}{c}33.3 \mathrm{~cm} \\
\left(1399 \mathrm{~m}^{3} / \mathrm{fed} .\right)\end{array}$ & $\begin{array}{c}21.8 \mathrm{~cm} \\
\left(916 \mathrm{~m}^{3} / \mathrm{fed} .\right)\end{array}$ & $\begin{array}{c}12.95 \mathrm{~cm} \\
\left(544 \mathrm{~m}^{3} / \mathrm{fed} .\right)\end{array}$ \\
\hline Effective rainfall $^{*}$ & & $\begin{array}{c}5.80 \mathrm{~cm} \\
\left(244.0 \mathrm{~m}^{3} / \mathrm{fed} .\right)\end{array}$ & $\begin{array}{c}5.80 \mathrm{~cm} \\
\left(244.0 \mathrm{~m}^{3} / \mathrm{fed} .\right)\end{array}$ & $\begin{array}{c}5.80 \mathrm{~cm} \\
\left(244.0 \mathrm{~m}^{3} / \mathrm{fed} .\right)\end{array}$ & $\begin{array}{c}5.80 \mathrm{~cm} \\
\left(244.0 \mathrm{~m}^{3} / \mathrm{fed} .\right)\end{array}$ \\
\hline $\begin{array}{l}\text { Irrigation water } \\
\text { requirements (IWR) }\end{array}$ & & $\begin{array}{c}47.2 \mathrm{~cm} \\
\left(1982 \mathrm{~m}^{3} / \mathrm{fed} .\right)\end{array}$ & $\begin{array}{c}39.1 \mathrm{~cm} \\
\left(1642 \mathrm{~m}^{3} / \mathrm{fed} .\right)\end{array}$ & $\begin{array}{c}27.6 \mathrm{~cm} \\
\left(1159 \mathrm{~m}^{3} / \mathrm{fed} .\right)\end{array}$ & $\begin{array}{c}18.8 \mathrm{~cm} \\
\left(790 \mathrm{~m}^{3} / \mathrm{fed} .\right)\end{array}$ \\
\hline
\end{tabular}

${ }^{\star}$ Effective rainfall $=$ incident rainfall x 0.7 (Novica, 1979)

Faba bean water use amounts vary with the amount of water available to the plant from the soil and how much comes as rainfall during the growing season. For faba bean to grow without water stress in North Delta, Egypt, approximately $41.4 \mathrm{~cm}\left(1739 \mathrm{~m}^{3} / \mathrm{fed}\right.$.) of water would be required. This could 
come as a combination of stored soil water, growing season rainfall, and irrigation.

Crop water use efficiency (CWUE):

Crop water use efficiency expressed in $\mathrm{kg}$ of seed yield/ $\mathrm{cm}$ of water consumed is presented in Table 7. Results obtained showed that CWUE increased with low irrigation frequencies. Irrigation treatment of $I_{1}$ resulted in the highest value of CWUE to be $109.0 \mathrm{~kg}$ of seed yield $/ \mathrm{cm}$ of water consumed, while the lowest one was $54.5 \mathrm{~kg}$ of seed yield/cm of water consumed, resulted from irrigation treatment of $\mathrm{I}_{4}$. These findings could be attributed to the high significant differences among seed yield of faba bean cultivars in addition differences between water consumptive use occurs among faba bean cultivars. The present results are in line with those reported by Hassanein (2000), Ragheb et al., (2000) Oweis and Hachum (2003). Shawky, et al. (2004) and Meleha et al., (2004) who mentioned that the efficiency of water use had decreased as the soil moisture was maintained high by the frequent irrigation.

Table (7): Average crop water use efficiency ( $\mathrm{kg}$ seed yield/cm of irrigation water consumed) as affected by irrigation treatments and faba bean cultivars over both growing seasons (2005/06 and 2006/07).

\begin{tabular}{|c|c|c|c|c|c|}
\hline Variables & \multicolumn{4}{|c|}{ Irrigation treatments } & Mean \\
\hline & $\mathbf{I}_{\mathbf{4}}$ & $\mathbf{I}_{\mathbf{3}}$ & $\mathbf{I}_{\mathbf{2}}$ & $\mathbf{I}_{\mathbf{1}}$ & \\
\hline Faba bean cultivars: & & & & & \\
Sakha 1 & $52.5 \mathrm{k}$ & $57.9 \mathrm{~g}$ & $66.2 \mathrm{e}$ & $113.4 \mathrm{a}$ & $72.5 \mathrm{~B}$ \\
Sakha3 & $56.8 \mathrm{~h}$ & $67.3 \mathrm{de}$ & $68.0 \mathrm{~d}$ & $104.0 \mathrm{~b}$ & $74.0 \mathrm{~A}$ \\
Nubaria 1 & $54.3 \mathrm{i}$ & $62.5 \mathrm{f}$ & $67.5 \mathrm{de}$ & $109.7 \mathrm{c}$ & $73.5 \mathrm{AB}$ \\
\hline Mean & $54.5 \mathrm{D}$ & $62.6 \mathrm{C}$ & $67.2 \mathrm{~B}$ & $109.0 \mathrm{~A}$ & \\
\hline
\end{tabular}

Means designed by the same letter at each cell are not significantly different at the $5 \%$ level according to Duncan's multiple range test.

As for faba bean cultivars, data in Table 7 showed that faba bean cv. Sakha 3 significantly increased CWUE by $2.1 \%$ and $0.7 \%$ compared to faba bean cvs. Sakha 1 and Nubaria 1, respectively. It means that faba bean cv. Sakha 3 and Nubaria 1 utilized irrigation water more efficiently than faba bean cv. Sakha 1.

The interaction between irrigation treatments and cultivars in Table 7 showed that the highest CWUE was $113.4 \mathrm{~kg}$ seed yield $/ \mathrm{cm}$ of water consumed resulted from irrigation treatment of $\mathrm{I}_{1}$ using faba bean $\mathrm{cv}$. Sakha 1 while the lowest one was $52.5 \mathrm{~kg}$ seed yield $/ \mathrm{cm}$ of water consumed resulted from irrigation treatment of $\mathrm{I}_{4}$ using faba bean cv. Sahka 1 . In this respect, the water use efficiency of faba bean cultivars increased markedly with increasing water deficit. So, water use efficiency significantly varied among the cultivars.

2.4. Field water use efficiency (FWUE):

Mean values of field water use efficiency as affected by irrigation treatments and faba bean cultivars are presented in Table 8. Results indicated that the highest values of FWUE were recorded from the irrigation 
treatment of $I_{1}$ whereas the lowest one was obtained from irrigation treatment of $\mathrm{I}_{4}$. These results could be attributed to the significant differences among faba bean seed yield, and evapotranspiration due to water applied values. It can be recommended to irrigate faba bean 3 times including sowing irrigation since the reduction in seeds yield was $1.4 \%$ against $17.2 \%$ of saving irrigation water applied compared with irrigation 4 times.

Data illustrated in Table 8 showed that the three tested cultivars were differed significantly with regarding to FWUE. Faba bean cultivars cv. Sakha 3 exceeded faba bean cvs. Sakha 1 by $10.6 \%$ and Nubaria 1 by $4.5 \%$, respectively.

The interaction between irrigation treatments and cultivars in Table 8 showed that the highest FWUE was $72.1 \mathrm{~kg}$ seed yield/cm of water applied resulted from irrigation treatment of $\mathrm{I}_{1}$ using faba bean $\mathrm{cv}$. Sakha 3 while the lowest one was $31.3 \mathrm{~kg}$ seed yield $/ \mathrm{cm}$ of water applied resulted from irrigation treatment of $\mathrm{I}_{4}$ using faba bean cv. Sahka 1.

Table (8):Average field water use efficiency $(\mathrm{kg}$ seed yield/cm of water applied) as affected by irrigation treatments and faba bean cultivars over both growing seasons (2005/06 and 2006/07).

\begin{tabular}{|c|c|c|c|c|c|}
\hline \multirow{2}{*}{ Variables } & \multicolumn{4}{|c|}{ Irrigation treatments } & \multirow{2}{*}{ Mean } \\
\cline { 2 - 5 } & $\mathbf{I}_{\mathbf{4}}$ & $\mathbf{I}_{\mathbf{3}}$ & $\mathbf{I}_{\mathbf{2}}$ & $\mathbf{I}_{\mathbf{1}}$ & \\
Faba bean cultivars: & & & & & \\
Sakha 1 & $31.3 \mathrm{l}$ & $37.5 \mathrm{~h}$ & $52.0 \mathrm{e}$ & $70.6 \mathrm{~b}$ & $47.9 \mathrm{C}$ \\
Sakha3 & $37.8 \mathrm{i}$ & $45.1 \mathrm{f}$ & $56.9 \mathrm{c}$ & $72.1 \mathrm{a}$ & $53.0 \mathrm{~A}$ \\
Nubaria 1 & $35.1 \mathrm{k}$ & $41.5 \mathrm{~g}$ & $55.4 \mathrm{~d}$ & $70.9 \mathrm{~b}$ & $50.7 \mathrm{~B}$ \\
\hline Mean & $34.8 \mathrm{D}$ & $41.4 \mathrm{C}$ & $54.8 \mathrm{~B}$ & $71.2 \mathrm{~A}$ & \\
\hline
\end{tabular}

Means designed by the same letter at each cell are not significantly different at the $5 \%$ level according to Duncan's multiple range test.

\section{Soil moisture extraction pattern (SMEP):}

Data of mean values of soil moisture extraction percentages in the upper $60 \mathrm{~cm}$ of soil depth are presented in Table 9 . Results showed that the highest percentage of moisture uptake was occurred at the surface layer 15 $\mathrm{cm}$ of the soil profile, while less water was extracted from the successive depths. Means percentage values of water removed from the upper $30 \mathrm{~cm}$ soil layer were $76.93 \%, 72.20 \%, 66.43 \%$ and $63.48 \%$ from $0-30 \mathrm{~cm}$ soil layer for $I_{4}, I_{3}, I_{2}$, and $I_{1}$ respectively. However, the respective values were 23.07, $27.80,33.57$ and $36.52 \%$ withdrawn from the lower $30-60 \mathrm{~cm}$. These values showed that when the soil is kept wet due to multiple irrigation, more water is extracted from the upper $30 \mathrm{~cm}$ soil layer. On the other hand, when soil moisture content of the surface layer was subjected to water deficit, as a result of irrigation treatment of $I_{1}$, plants of faba bean tended to extract its water requirements from deeper soil layers. These findings could be attributed to the fact that most of faba bean plants roots are concentrated in the upper soil layers and those roots are the most effective in water extraction. Similar results were found by Chimenti et al. (2006) who showed that crops extracted significant more water from deeper layers in the soil profile during the stress period. 
As for faba bean cultivars, data in Table 9 showed that there is no effect on this trait, and the values were about the same.

Table (9): Percentage of soil moisture extraction by roots form different layers as affected by irrigation treatments and faba bean ultivars, over both seasons.

\begin{tabular}{|c|c|c|c|c|c|c|c|}
\hline \multirow{2}{*}{$\begin{array}{l}\text { Irrigation } \\
\text { treatments }\end{array}$} & \multirow{2}{*}{$\begin{array}{c}\text { Faba } \\
\text { bean } \\
\text { cultivars }\end{array}$} & \multicolumn{4}{|c|}{$\begin{array}{l}\text { Percentage of soil moisture extraction } \\
\text { in different soil depths }(\mathrm{cm})\end{array}$} & \multicolumn{2}{|c|}{ Mean of SMEP } \\
\hline & & $0-15$ & $15-30$ & $30-45$ & 45- 60 & $0-30$ & $30-60$ \\
\hline \multirow{3}{*}{$\mathrm{I}_{4}$} & Sakha 1 & 49.60 & 27.02 & 16.82 & 6.56 & 76.62 & 23.38 \\
\hline & Sakha3 & 49.84 & 27.32 & 17.06 & 5.78 & 77.17 & 22.84 \\
\hline & Nubaria 1 & 49.78 & 27.21 & 17.00 & 6.01 & 76.99 & 23.01 \\
\hline \multicolumn{2}{|c|}{ Mean } & 49.74 & 27.18 & 16.96 & 6.12 & 76.93 & 23.07 \\
\hline \multirow{3}{*}{$I_{3}$} & Sakha 1 & 44.53 & 27.40 & 18.20 & 9.87 & 71.93 & 28.07 \\
\hline & Sakha3 & 44.77 & 27.65 & 18.46 & 9.12 & 72.42 & 27.58 \\
\hline & Nubaria 1 & 44.68 & 27.58 & 18.40 & 9.34 & 72.26 & 27.74 \\
\hline \multicolumn{2}{|c|}{ Mean } & 44.66 & 27.54 & 18.35 & 9.44 & 72.20 & 27.80 \\
\hline \multirow{4}{*}{$\mathbf{I}_{2}$} & Sakha 1 & 38.45 & 27.64 & 20.16 & 13.75 & 66.09 & 33.91 \\
\hline & Sakha3 & 38.72 & 27.96 & 20.40 & 12.92 & 66.68 & 33.32 \\
\hline & Nubaria 1 & 38.63 & 27.88 & 20.25 & 13.24 & 66.51 & 33.49 \\
\hline & & 38.60 & 27.83 & 20.27 & 13.31 & 66.43 & 33.57 \\
\hline \multirow{3}{*}{$\mathbf{I}_{1}$} & Sakha 1 & 35.19 & 28.01 & 21.44 & 15.36 & 63.20 & 36.80 \\
\hline & Sakha3 & 35.44 & 28.34 & 21.64 & 14.58 & 63.78 & 36.22 \\
\hline & Nubaria 1 & 35.36 & 28.10 & 21.55 & 14.99 & 63.46 & 36.54 \\
\hline \multicolumn{2}{|c|}{ Mean } & 35.33 & 28.15 & 21.54 & 14.98 & 63.48 & 36.52 \\
\hline \multirow{3}{*}{$\begin{array}{l}\text { Mean of } \\
\text { irrigation }\end{array}$} & Sakha 1 & 41.94 & 27.52 & 19.16 & 11.39 & 69.46 & 30.54 \\
\hline & Sakha3 & 42.19 & 27.82 & 19.39 & 10.60 & 70.01 & 29.99 \\
\hline & Nubaria 1 & 42.11 & 27.69 & 19.30 & 10.90 & 69.80 & 30.3 \\
\hline \multicolumn{2}{|c|}{ Overall mean } & 42.08 & 27.68 & 19.28 & 10.96 & 69.76 & 30.24 \\
\hline
\end{tabular}

Regression and correlation coefficient:

Equations in Table 10 indicated that each centimeter of water applied produced $10.5 \mathrm{~kg}$ seed yield/fed. and enhanced water consumptive use of faba bean plants by $0.6 \mathrm{~cm}$.

Table (10): Regression equations and correlation coefficient $(r)$ between irrigation water requirement in $\mathrm{cm}$ (IWR) and each seed yield in $\mathbf{~ k g} / \mathrm{fed}$., water consumptive use (cm), crop water use efficiency (CWUE) and field water use efficiency (FWUE).

\begin{tabular}{|c|c|c|}
\hline Variables & Equation & $\mathbf{r}$ \\
\hline Seed yield & $\hat{Y}=1178+10.5($ IWR $)$ & $0.96^{\text {** }}$ \\
\hline CU & $\hat{Y}=3.2+0.6($ IWR $)$ & $0.94^{\text {** }}$ \\
\hline CWUE & $\hat{Y}=130-1.7($ IWR $)$ & $-0.80^{\text {** }}$ \\
\hline FWUE & $\hat{Y}=93-1.3($ IWR $)$ & $-0.79^{\star *}$ \\
\hline
\end{tabular}

On the other hand, the increments in irrigation water requirements for faba bean plants decreased crop water use efficiency (CWUE) by $1.7 \mathrm{~kg}$ seed yield/cm of water consumed and field water use efficiency (FWUE) by $1.3 \mathrm{~kg}$ seed yield $/ \mathrm{cm}$ of water applied as shown in Table (9). This results 
because an irrigation water requirement (IWR) is essential to develop a large plant canopy and early ground cover to increase yield of seeds of faba bean. Irrigation water requirements (IWR) was significantly and positively correlated with seed yield $(r=0.96)$, and water consumptive use $(r=0.94)$. However, it was negatively correlated with CWUE $(r=-0.80)$ and FWUE $(r=-0.79)$.

\section{REFERENCES}

Abbsa, F. A ९; M.M. A. Saeed and A.M. Osman (1994). Response of faba bean yield to soil moisture content and rainfall at Nobaria, Egypt. Egypt. J. Appl. Sci. 9(4): 302-314.

Abd El-Mottaleb, and F.A.H. Abbas, (1992). Effect of irrigation regime on growth and yield of broad bean (Viciaa faba L.). Menofiya Univ. J. Agric. Res., 17(4): 2183.

Ainar, N.G.; W.I. Miseha and H.H. Abdelal (1993). Water management for faba bean in the Delta. Zagazig J. Agric. Res. 20 (6): 2045-2053.

Amede, T; E.V. Kittlitz; S. Schubert (1999). Differential drought responses of faba bean (Vicia faba L.) inbred lines. Journal of Agronomy and Crop Science. 183(1): 35-45

Amer, M.A., A.H. A. Hussein, M.A. El-Borai, Ola, A.M. El-Galaly, R.A. AbouMostafa, Sabah, M. Attia, N.M. Abou-Zeid, and Negwa M.A.Mahmoud (2006). Sakha 3; A new high yielding and foliar disease resistant faba bean cultivar. First field crops conference, Giza Egypt. pp. 192-197.

Chimenti, C.A.; M. Marcantono, and A.J. Hall (2006). Divergent selection for osmotic adjustment results in improved drought tolerance in maize (Zea mays L.) in both early growth and flowering phases. Field Crops Research, 95(2/3): 305-315.

Costa, W. A.J.M.; M.D. Dennett; U. Ratnaweera and K. Nyalemegbe (1997). Effects of different water regimes on field-grown determinate and indeterminate faba bean (Vicia faba L.). I. Canopy growth and biomass production.Field Crops Research. 49(2/3): 83-93.

Duncan, B.D. (1955). Multiple range and multiple F-test. Biometric., 11: 1-42.

Egyptian Meteorological Authority (1960). Climatological Normals for United Arab Republic up to 1960, Cairo. p 4.

El-Deep, M.A., H.A. Hussein, Kh. M. Yamani, and T.S.A. El-Marsafawy (2006). Response of new faba bean genotypes to different sowing dates and plant densities in the new valley. First field crops conference, Giza Egypt. pp. 358-362.

El-Galfy, A. M.K. (2005). Effect of some irrigation treatments on yield, yield components and seed quality characteristics of some faba bean (Vicia faba L.) varieties. Annals of Agric. Sci., Moshtohor. 43 (1): 51-62.

Fardos, R.H. and A.Sh. Abdel Nour. (2000). Soil moisture stress and phosphorus fertilizer interrelations of faba bean under sandy soil condition. Egypt. J. Appl. Sci., 15(4): 134-151.

Hansen, V.W.; D.W. Israelsen and Q.E. Stringharm (1979). Irrigation principle and practices, 4th ed. John Wiley as sons,. New York. 
Hassanein, M. S. (2000). Response of some faba bean varieties to water supply. Annals of Agric. Sci., Moshtohor. 38 (3): 1383-1398.

Jensen, M.E. (1983). Design and operation of farm irrigations systems. Amer. Soc. Agric. Eng. Michigan, USA.

Klute, A. (1986). Methods of Soil Analysis. Part 1. 2nd ed. ASA and SSSA. Madison, Wisconsin, USA.

Meleha, M.E.; G.M. Fawzi and U.M. gawish (2004). Effect of irrigation water management on yield of broad bean and water use efficiency. Egypt. J. Appl. Sci. 19(12B): 787-799.

Michael, A. M. (1978). Irrigation theory and practice. Vikas Publishing House PVT LTD New Delhi, India

Mohamed,A. A; E. N. Gendy, and S. R Saleeb. (1999). The combined effect of irrigations number and gypsum applications on faba bean (Vicia faba L.) yield and its main components. Annals of Agricultural Science, Moshtohor. 1999; 37(4): 2805-2812

Oweis, T. Y. and A. Y. Hachum (2003). Improving water productivity in the dry areas of West Asia and North Africa. Water productivity in agriculture: limits and opportunities for improvement. 179-198

Page, A.L. (ed.) (1982). Methods of Soil Analysis. Part 2. $2^{\text {nd }}$ ed. ASA and SSSA, Madison, Wisconsin, USA.

Plies, B., E.; T. Kong; S. Schubert and K. Mengel, (1995). Effect of water stress on plant growth, nitrogenase activity and nitrogen economy of four different cultivars of Vicia faba L. European J. Agron. 4(2): 167173. (C.F. Field Crop Bastract, 1995).

Ragheb, H.M; M.A Gameh; M.H Nafady and A. R. Ahmed (2000). Growth, yield, water use efficiency and nutrients contents of two bean varieties under trickle and sprinkler irrigation regimes in the New Valley. Assiut Journal of Agricultural Sciences. 31(2): 89-117

Sau, F and M.I. Minguez (2000). Adaptation of indeterminate faba beans to weather and management under a Mediterranean climate. Field Crops Research. 66(1): 81-99.

Shawky,M.E; R. E Sabrah; H.M Nasr; F.A Gomaa, and T.H. Borham, (2004). Studies on water requirements for wheat and faba bean crops under different cropping systems. Egyptian Journal of Soil Science. 44(1): 129-145

Snedecor, G.W. and W.G. Cochran (1980). Statistical methods 7th ed. lowa State Univ., Press, Ames, lowa, USA.

Tawadros, H.W.; W.I. Miseha; M.F. Wabba and B.H. Nageib. (1993). Effect of withholding irrigation at different stages of plant growth on faba bean. Egypt. J. Appl. Sci., 8(8): 123-141.

Xia, M.Z. (1997). Effect of soil drought during the generative development phase on seed yield and nutrient uptake of faba bean (Vicia faba). Australian J. of agric. Res. 48(4): 447-451.

Younis, M.E; O.A. El-Shahaby; M.N.A Hasaneen, and M. Gaber (1993). Influence of different water treatments on stomatal apparatus, pigments and photosynthetic capacity in Vicia faba. Journal of Arid Environments. 25(2): 221-232. 
تأثير الرى على إنتاجية وكفاءة استخدام المياه لبعض أصناف الفول البلاى بمنطقة

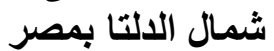

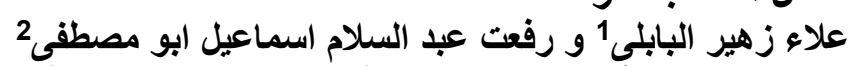

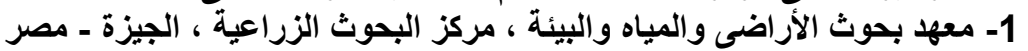

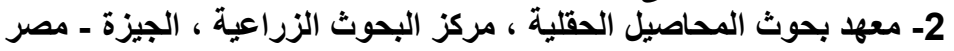

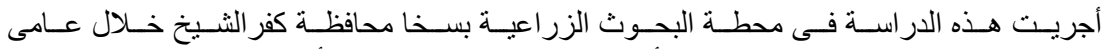

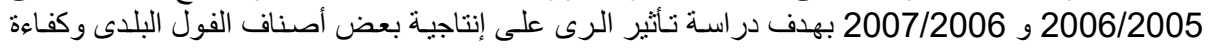

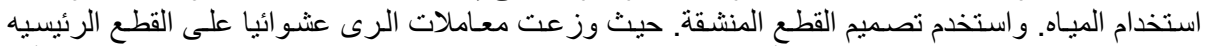

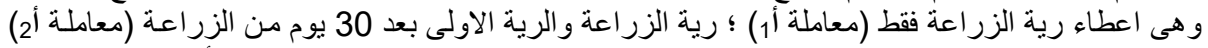

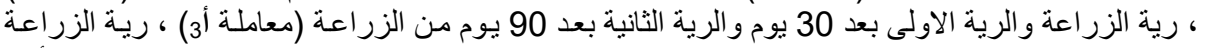

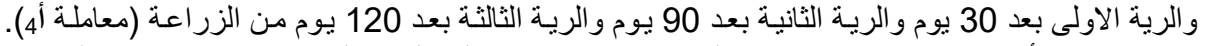

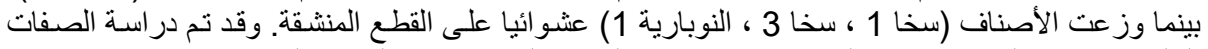

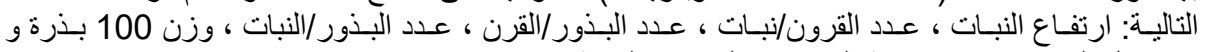
محصول البذور/فدان بالإضافة إلى بعض العنات العلاقات المائية. ويمكن تلخيص أهم النتائج فى الآتى:

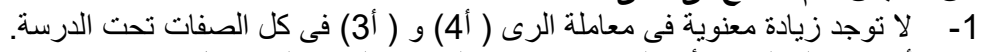

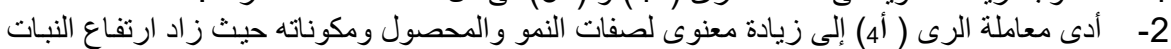

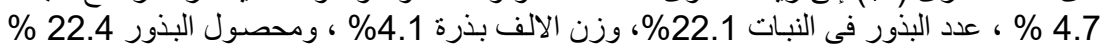

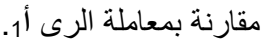

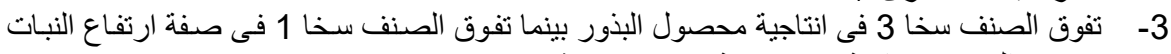
و تفوق الصنف نوبارية 1 فى صفة ولئة وزن 100 بذرة.

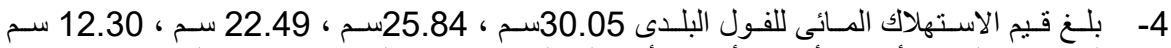

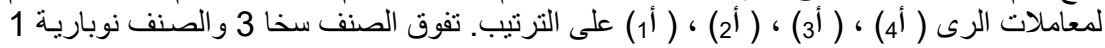

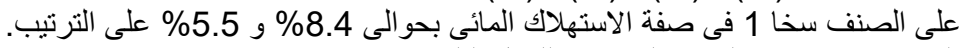

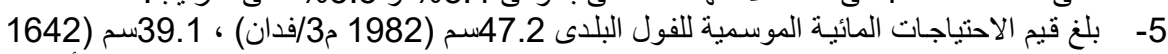

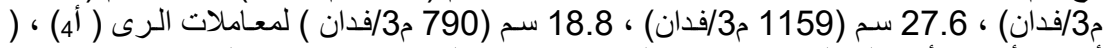

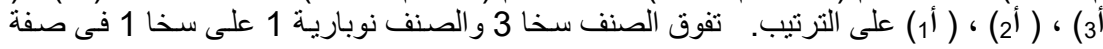

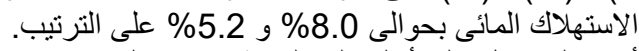

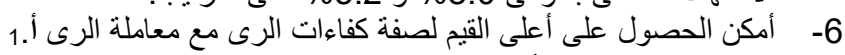

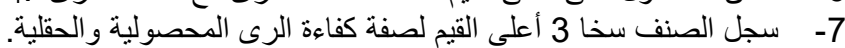

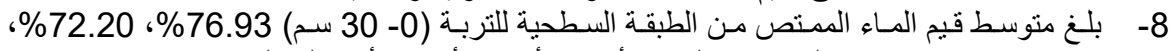

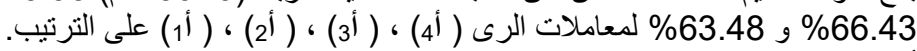

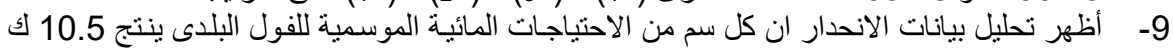

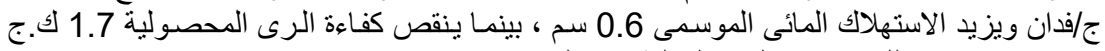

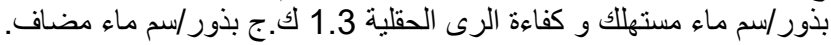

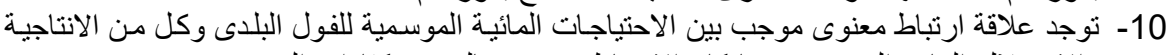

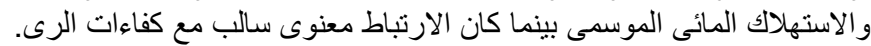

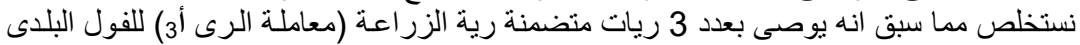

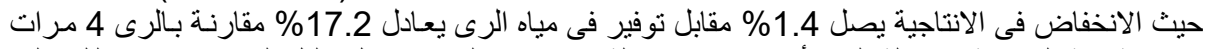

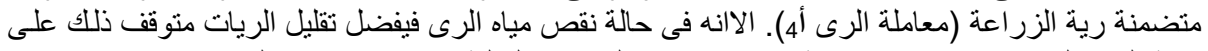

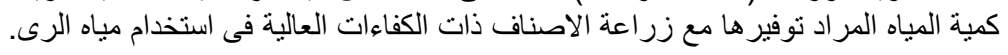

